\title{
Factors Influencing the Effects of Large-Scale Land Acquisition on The Livelihood of Smallholder Farmers in the Pru District of Ghana
}

\author{
Charles Quansah, PhD \\ Kwame Nkrumah University of Science and Technology (KNUST), College \\ of Humanities and Social Sciences Faculty of Social Sciences, Department \\ of Geography and Rural Development, Ghana \\ Agyemang Frimpong, PhD \\ Ronald Osei Mensah, PhD Student \\ Ghana Institute of Management and Public Administration (GIMPA), School \\ of Public Service and Governance, Department of Public Management and \\ International Relations, Ghana, University of Cape Coast (UCC), College of \\ Humanities and Legal Studies/Faculty of Social Sciences \\ Department of Sociology and Anthropology, Ghana
}

Doi:10.19044/esj.2020.v16n11p159 URL:http://dx.doi.org/10.19044/esj.2020.v16n11p159

Abstract

This study is undertaken to find out the factors influencing the effects of large-scale land acquisition on the livelihood of smallholder farmers in the Pru district. An important driver for large-scale land acquisition in Ghana, and the rest of Africa, is the growing global demand for biofuels and other plantations. Methodologically, mixed method approach was adopted by applying both quantitative and qualitative research designs. Quantitative data was obtained through a cross-sectional survey from smallholder farming households in the study communities of the Pru District with the help of a multi-stage sampling technique and cluster sampling technique. Qualitative data was obtained through Focus Group Discussions (FGD) from farmerbased associations in the Pru district. The Pru district in the Bono East region was purposively selected based on the reason that it is the most affected district with activities of land grabbing in Ghana. Based on the sample frame of 2,554 households in the communities, a sample size of 346 was used for the study out of which 332 were households and 14 were investors and traditional authorities. The study revealed that household heads' level of education, sex of household heads, household engagement in off-farm activities, total farm land owned by a household, size of land lost by households to large-scale land investors, households' participation in decision making, and training of households for other alternative jobs significantly influence large-scale land 
acquisition on the livelihood of smallholder farming households. The study found out that the higher the level of education of a household head, the lesser the household suffers the adverse effects of losing their farm land to largescale land investors hence their livelihoods. It was revealed that some major factors that influenced large-scale land acquisition in the Pru district were the availability of land for the cultivation of plantations by investors, the soil fertility of the land in the district and the freedom and peace enjoyed by investors to go about their businesses and enjoying good tax exemptions in such an environment thus Pru district.

Keywords: Large-scale land acquisition, livelihood, smallholder farmers, household, household head, Pru district

\section{Introduction}

An important driver for large-scale land acquisition in Ghana, and the rest of Africa, is the growing global demand for biofuels and other plantations. The period from 2005 until now has experienced unprecedented growth in global biodiesel demand and production (Biofuels International, 2007). Biofuels accounted for 2.7 percent of all global fuel for road transportation in 2010 (Kemausuour, Akowuah \& Ofori, 2013). Global demand for biofuel was projected to increase to about 183.8 billion litres by 2015 (Antwi, Bensah, Quansah, Arthur \& Ahiekpor, 2010). The increasing demand for biofuels can be explained partly by the mandatory targets set by governments to reduce their dependence on fossil fuels in order to mitigate their footprints on the environment and ultimately the climate (Antwi, Bensah, Quansah, Arthur \& Ahiekpor, 2010; Kemausuour, Akowuah \& Ofori, 2013; Sindayigaya, 2011).

Despite the known adverse effects of large-scale land acquisition for investments on the livelihood of smallholder farmers, governments in many developing countries are almost always willing to accept these investments in the name of Foreign Direct Investments (FDIs). This phenomenon is not new to Ghana as vast areas of land have been acquired and used for the purposes of establishing plantations. In Ghana, the National Jatropha Plantation Initiative (NJPI), which was initiated in 2006, had a target of developing up to one million hectares of jatropha plantations by the year 2010. Up to date, literature is silent on whether this target has been achieved or not. However, Hughes, Knox \& Jones-Casey (2011), identified over 20 companies, mostly foreign owned, that are cultivating large scale jatropha and other plantations in Ghana.

In another development, some pragmatic and realistic factors have promoted the concept of large-scale land acquisition by neglecting the wellbeing of the locals. Investors quest to satisfy global food crisis and save the environment from pollution through the production of biofuel such as 
jatropha has brought about large-scale land acquisition, thereby worsening the conditions of the smallholder farmers' in terms of their livelihood. Some areas where land has been acquired for projects, plantation and other social and economic needs and services are rural areas in Africa, Southern America, Eastern Europe and others where occupants of such lands are smallholder farmers. These investors and developed companies acquired such assets such as land, without investing in their economies and life development, but rather repatriate the profits to their countries further worsen the livelihoods of the local people (Kotey, 2002; Borras \& Franco, 2010).

The desire to achieve energy efficiency, increase production, maximise profits, expand to other nations, and achieve food sufficiency explains why rich individuals, international and multi-national companies, corporations and governments are playing leading roles in the recent investments in large-scale land acquisitions in Latin America, Eastern Europe and Africa, (Cotula, Vermeulen, Leonard \& Keeney, 2009).

\section{Objective of the Study}

The objective of this study is to find out the factors influencing the effects of large-scale land acquisition on the livelihood of smallholder farmers in the Pru district of Ghana.

\section{Literature Review}

\section{Trend in Africa and Major Investor}

Africa is identified to be one of the most attractive continents for largescale plantation due to its favourable environment, political, and socio-cultural environment for the large-scale production of feedstock such as jatropha, rice, cashew and others. This has led to influx of both international and local investors into the plantation business. Mali and the Cape Verde Islands have a long experience in cultivation of jatropha providing for domestic energy supply. Literature reveals three broad categories of investors in Africa. These are the oil-rich Gulf States like Saudi Arabia, United Arab Emirates, Qatar, Bahrain, Oman, Kuwait and Jordan; Asian countries such as China, South Korea, Japan and India; as well as western and multinational private companies (Friis \& Reenberg, 2010).

The Ghana government published a strategic energy plan in 2006 which aim at producing $10 \%$ of biodiesel by the end of 2015. It was also mandated to produce biodiesel for electricity and transport by the end of 2020 (Hamenoo, 2014). This was in response to global and domestic needs. Hamenoo however stressed that, there are 17 commercial biofuel development that have been identified in Ghana. Out of these, 15 are owned by foreign companies and financed by some individual Ghanaians. According to Schoneveld, German \& Nutakor (2011) policy brief on large-scale land 
acquisition identified an estimate of 1,075,000-hectare acres of lands located in the forest-savannah transition zone comprising Northern, Bono East and Ashanti Region of Ghana owned by foreign companies.

\section{Drivers of Large-Scale Land Acquisition}

According to the Energy Center (2008), it is the environmental consequences of fossil fuels on the atmosphere, a phenomenon which has been shown to be responsible for global warming and the high cost of fuel that has stimulated the drive to look for these alternative sources of energy. This drive became necessary in reducing dependence on fossil fuels with clean energy as a long-term effort for climate change mitigation (Antwi, Bensah, Quansah, Arthur \& Ahiekpor, 2010; Kemausuor et al., 2013; Sindayigaya, 2011). Since 2005, there had been an unprecedented growth in global biodiesel demand, production, and production capacity (Biofuels International, 2007; Action Aid, 2009). Because several studies (Herzog, Fahle \& Koch, 2001, Cotula et al., 2008, GEXSI, 2008) have shown the biodiesel potential of such products as jatropha over the last decade, development and demands for these products continue to rise within and between countries. The increasing demands for traditional feedstocks (raw materials) have contributed to a host of concerns on the implication these trends could offer for access to land and food crop production (Thurmond, 2007). It is indeed remarkable to recall that,

"...the world's population has tripled since the

United Nations was created immediately after the

Second World War. And our numbers keep

growing. So, do the pressures on land, energy, food and water".

(Banki Moon, 2011. 66th UN General Assembly Address: "We the Peoples" by the UN Secretary-General, 21 September 2011).

\section{Effects of Large-Scale Land Acquisition on Livelihood}

Despite evidenced researches on the ability of large-scale land acquisition to providing a safe, cost effective and sustainable bioenergy which gained grounds after the escalating global oil prices in 2006, (Schenoveld \& German, n.d), a lot of questions have been raised by many researchers and some developing countries concerning the net impacts of large-scale land acquisition for plantation on the livelihoods of people in project communities. Schoneveld, German \& Nutakor (2011) summarizes that, Large-Scale land acquisition for plantation could either make invaluable contribution to reducing rural poverty or worsened the socio-economic conditions and environment of project-based communities.

Supportively, Danso (2015) opines that, plantation could be used as a means to developing rural communities when the project adheres and 
considers the traditional land tenure systems with the consent of host communities. Levidow \& Helena (2010), also sees the positive facet of largescale land acquisition purposively for plantation, positing that large-scale land acquisition for jatropha and biofuel production will not divert resources from food production.

In contrast, a number of researchers stand tall disapproving large-scale land acquisition for jatropha plantation; postulating that the situation has rather worsened livelihoods of host communities. Matondi et al., (n.d) adds that there still persist arguments on the local benefits among advocates of biofuels in terms of employment creation, infrastructure, higher standards of living among others. In some extreme instances, Levidow \& Paul (2010) notes that large-scale plantation cultivation has actually generated conflicts over resources in Africa (notably in Mozambique and Tanzania) and Asia. This occurs when most projects have led to the lost or damage to the livelihood assets of host communities with Schoneveld (2010) warning that the phenomenon can significantly exacerbate rural poverty as communities lose access to vital livelihood resources. Matondi, Havnevik \& Beyen (n.d) relates from the minister of energy in Mozambique that about 41 million hectares of marginal land could be used for plantation such as jatropha, cashew, mango oil palm among others and other 36 million hectares could be used for biofuel cultivations without a threat to food production.

Buttressing the stance of the opponents to large-scale land acquisition for jatropha plantations, (Schoneveld, 2010; Action-Aid, 2010a, 23), cited in Daley, (2011) recounts the ordeal women farmers in Mozambique and Tanzania wallowed in after losing their farm lands to plantations cultivation. This presuming means the farmers have lost their assets, the only farm lands on which their livelihood depended. Action-Aid $(2010 \mathrm{~b}, 28)$ presented a similar case, cited in Daley, (2011) that a good number of Ghanaians and Senegalese have lost their "marginal" lands on which was their main source of food, fuel and incomes.

\section{Research Methodology}

The Pru District was created on the 18th of February, 2004 under Legislative Instrument (L.I) 1778 of 2004. Pru District was created out of the former Atebubu district. The physical, economic and socio-cultural conditions have shaped and influenced lives in the Pru District. It is therefore relevant to put these issues into perspective to enable a fair appreciation of the current state of the district. There are core natural and anthropogenic factors that have influenced economic production, consumption, reproduction, health, sanitation and the overall welfare of the people in the Pru district.

The study communities included Kobre, Kadue, Abease, Prang and Adjentura. 
The Pru district lies between Longitudes 0030 "W and 1026"W and Latitudes 7050"N and 8022"N. It shares boundaries with seven other districts, namely East Gonja to the North (Northern Region), Sene East and West to the East, Nkoranza and Atebubu-Amantin to the South and Kintampo-North and South to the West, all in the Bono East Region. The district covers an area of $3220.7 \mathrm{kmsq}$.

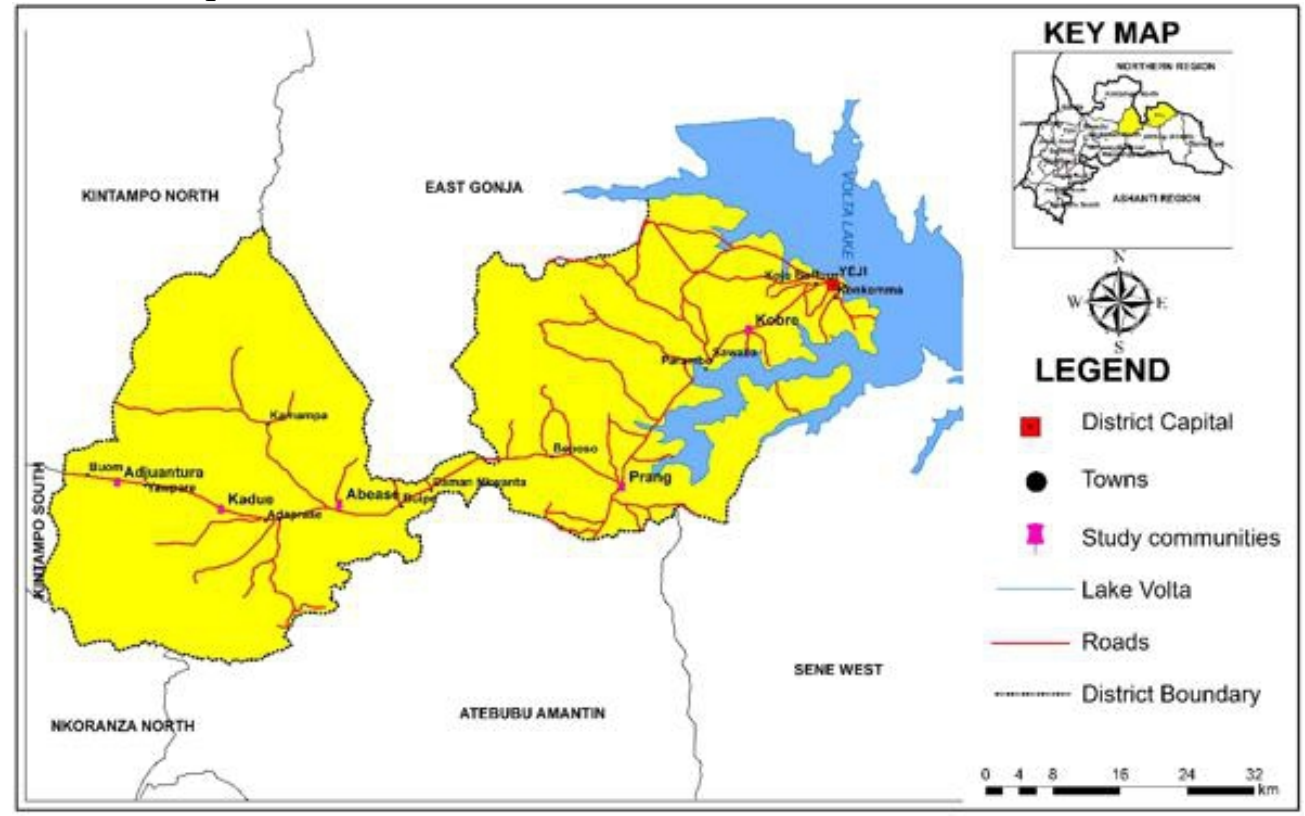

Figure 1: Map of Pru District showing the study communities

(Ghana Statistical Survey, 2015)

\section{Research Approach}

Survey research approach was used for the study. The survey research was considered to be most appropriate research approach to provide the required quantitative descriptions of the factors influencing the effects of large-scale land acquisition in the Pru District. Data from farming households were gathered using structured questionnaires. The research further collected a mixture of quantitative and qualitative (descriptive) data. The approach makes provision for quantitative method (designed to collect numbers) and qualitative method (designed to collect words/descriptive in nature). The study therefore used a combination of quantitative and qualitative methods to answer the research questions.

The methodological eclecticism inherent in the mixed research design results in superior results (Johnson and Onwuegbuzie, 2009). The strength of this strategy is that the weakness of one will be compensated for by using an alternative method (Bryman, 2008 cited in Alatinga and Fielmua, 2011). Focus group discussions have also been used to obtain qualitative data from 
farmer-based associations in the Pru District. The quantitative data were obtained through a cross-sectional survey from smallholder farming households in the study communities in the Pru District. A cross-sectional survey collects data to make inferences about a population of interest at one point in time. Cross-sectional surveys have been described as snapshots of the populations about which they gather data (Hall, 2008). Data was collected at one point of time in the Pru district which clearly describes the cross-sectional survey method.

The qualitative technique on the other hand was used to assess the coping and adaptation strategies adopted by smallholder farming households to abate the effects of large -scale land acquisition in the study communities of the Pru District. According to Morse and Field (1996), qualitative research refers to inductive, holistic, subjective and process-oriented methods used to understand, interpret, describe and develop a theory on a phenomenon or setting.

\section{Sample Size for the study}

Based on the sample frame $(\mathrm{N})$ of 2,554 households in the communities, a sample size (n) of 346 was derived for this study. Out of the 346-sample size, 332 were smallholder farming households whereas 14 were investors and traditional authorities who were interviewed. This was determined from the sampling frame using Slovin's mathematical method expressed by equation (1)

$$
n=\frac{N}{1+N(\ell)^{2}}
$$

Where ' $\mathrm{n}$ ' is the sample size, " $\mathrm{N}$ "' is the sample frame and " $\ell$ "' is the error margin. The use of the formula should contribute to ensuring reliability and validity in the research.

The sampling frame is the total number of units likely to be included in the study. In determining the sample size for the cross-sectional survey, a total of 332 sampled smallholder farming households were obtained from the communities in the Pru District at 95\% confidence level and 5\% error margin

\section{Sampling Techniques}

\section{The Cross-sectional Survey}

A multi-stage sampling technique was employed. Multi-Stage sampling is an extension of cluster sampling. It involves selecting the sample in stages that is taking samples from samples. It is the use of variety of sampling methods. Samples in the Pru district were taken in stages using smaller sampling units at each stage. Later, these samples were divided into various clusters in which affected communities in the district were captured. 
Cluster sampling ensured that all communities affected by land grabbing are represented in the final sample. Cluster sampling was used for the five (5) communities which were the focus of researchers. These five (5) communities were divided into cluster of groups comprising of Kobre, Kadua, Abease, Prang and Adjentura communities. After dividing the communities into various clusters, the researchers adopted to focus group discussions to solicit responses from respondents. The Pru district in the Bono East region was purposively selected based on the reason that it is the most affected with activities of land grabbing in Ghana. The last stage involved proportionate simple random sampling technique which was applied to select the smallholder farming households in each cluster (study communities).

\section{Description of the Study Site Results and Discussion}

Socio-Demographic Profile of Farming Households

The socio-demographic characteristics of farming households determine the magnitude of the factors influencing large-scale land acquisition. The socio-demographic characteristics of farming households considered by this study are age of household head, household size, household income per annum, and total acres of farm land owned by households, number of acres of farm land lost by farming households to large-scale land investors, sex of household head and the educational level of household head. This is presented in Table 1.

Table 1: Descriptive Statistics of Sampled Smallholder Farmers

\begin{tabular}{|c|c|c|c|c|}
\hline Variable & Mean & Std. Dev. & Min & Max \\
\hline Age of HHH & 35.49 & 1.27 & 24 & 58 \\
\hline Household Size & 5.40 & 3.00 & 1 & 18 \\
\hline Household income & 1700.83 & 78.04 & 180.00 & 3900.00 \\
\hline Land size owned By HH (acres) & 8.87 & 3.92 & 4 & 23 \\
\hline Land lost by HH to investors & 4.53 & 3.66 & 0 & 13 \\
\hline
\end{tabular}

Source: Field Survey, 2020

The youngest household head was 24 years while the eldest household head was 58 years. The average age of household heads in the Pru district was 35.49 years with a standard deviation of 1.27. This shows that the sampled households comprised of youthful members who can energetically carry out farming activities. Meanwhile, the minimum and maximum household sizes were 1 and 18 respectively with an average of 5.40 members. Larger household size is a source of labour for farming activities by a household. The mean household income was $\mathrm{GH} \phi 1700.83$ with a standard deviation of 78.04. The minimum and maximum household incomes were $\mathrm{GH} \not 180.00$ and GH $₫ 3900.00$ respectively. 
The size of farm land owned by a household also determines the extent to which households' livelihoods are adversely affected by large-scale land acquisition since there will still be enough farm land for cultivation by the household after relinquishing part of their lands to large scale land investors. The minimum and maximum farm land owned by sampled households was 4 acres and 23 acres respectively while the average farm land owned by households was 8.87 acres with a standard deviation of 3.92 acres. This reflects a typical smallholder farmers' in Ghana. Similarly, number of acres of land lost by farming households to large-scale land investors influences the magnitude of effect on households' livelihoods. The minimum and maximum size of land lost by households to large-scale land investors were 0 and 13 respectively. Averagely, each household lost 4.53 acres of land through largescale land acquisition.

A gender perspective is critical to truly understand the impact of largescale land deals, because women and men have different social roles, rights, and opportunities and will be differentially affected by any major change in tenurial regimes, especially land transfers to extra local investors (Behrman et al., 2012). In the literature, large-scale land acquisition has a disproportionate high effect on the livelihood of households headed by females than households headed by males, existing literature on the gender implications of the shift to large-scale commercial agriculture finds that these shifts often lead to changes in household dynamics and roles, income-generation activities, and property rights often to the detriment of women (Quisumbing, 1998). Also, the coping and adaptation strategies adopted by households depend on the sex of the household head.

\section{Factors Influencing the Effects of Large-Scale Land Acquisition on the Livelihood of Smallholder Farming Households}

The factors influencing the effect of large-scale land acquisition on the livelihood of farmers were determined using a simple linear regression model. The computed Livelihood Effect Index (LEI) was used as the dependent variable in the model with socio-economic and demographic characteristics of households being independent variables.

The regression results showed that the computed F statistic (9.497) was significant at 1 percent. This justifies the suitability of the simple regression model in determining the factors influencing the effects of large-scale land acquisition on the livelihood of farmers. The $\mathrm{R}^{2}$ value of 0.273 implies that about 27.3 percent of the effects of large-scale land acquisition on farmers' livelihood has been explained by the independent variables considered in the model.

The regression results revealed that with the exception of age of household heads and households' access to other farming inputs, all the other 
independent variables considered in the model had a significant effect on the dependent variable. This study discusses only the factors with significant influence on the livelihood of smallholder farmers. The result of the regression is presented in Table 2 .

Table 2: Regression Results of Factors Influencing the Effects of Large Scale Land Acquisition on Farmers' Livelihood

\begin{tabular}{|c|c|c|}
\hline Explanatory Variable & Coefficient & Std Error \\
\hline Constant & $0.566^{* * *}$ & 0.008 \\
\hline Education & $-0.246^{* * *}$ & 0.001 \\
\hline Sex of HHH & $-0.183^{* * *}$ & 0.002 \\
\hline Total HH farm size & $-0.368^{* * *}$ & 0.000 \\
\hline Farm size lost & $0.160^{* *}$ & 0.000 \\
\hline HH Participation in land acquisition process & $-0.131^{*}$ & 0.003 \\
\hline Access to labour & $-0.193^{* * *}$ & 0.003 \\
\hline Training for HH & $-0.168^{* * *}$ & 0.003 \\
\hline Off-farm activities & $-0.226^{* * *}$ & 0.002 \\
\hline Age of HHH & -0.065 & 0.000 \\
\hline Access to other farming inputs & 0,029 & 0.001 \\
\hline $\begin{array}{c}\text { № of Observation. = 332 F } \\
\text { P-Value }=0.000\end{array} \quad \mathrm{df}=10$ \\
\hline
\end{tabular}

Note: $*, * *$ and $* * *$ denotes statistically significant at $10 \%, 5 \%$ and $1 \%$ respectively. Source: Field Survey, 2020

The regression results revealed a significant negative relationship between a household head's years of education and the effect of large-scale land acquisition on the household. In effect, for every additional year of a household head's education leads to a reduction in the effects of large-scale land acquisition on the household by 24.6 percent. This suggests that the higher the level of education of a household head, the lesser the household suffers the adverse effects of losing their farm land to large-scale land investors. Thus, majority of the sampled households are severely affected by large-scale land acquisition by investors as a result of their heads not being educated.

Also, the sex of a household heads significantly determines the effect of large-scale land acquisition on the livelihood a household. Given that the sex variable was dummy with 1 representing male household head, the regression result on sex implies that households headed by males significantly reduce the effects of large-scale land investment on their households by 18.3 percent. About 73 percent of sampled household are headed by males and suggests that most households are capable of significantly reducing the effects of large-scale land acquisition on their households by 18.3 percent. According to Mutopo, Chiweshe \& Mubaya (2015), women farmers in Mwenezi of Zimbabwe feel the impact of large-scale land acquisition most because they 
have additional responsibility of caring for children, preparing food for the household, searching for water and attending to other household chores.

Another factor with significant negative influence on households' livelihoods attributable to large-scale land acquisition as revealed by the regression results is the total farm size owned by the household. The empirical results showed that for every additional acre of farm land owned by a household leads to a 36.8 percent reduction in the effects of large-scale land acquisition on the household's livelihood. Generally, households owning large farm lands will still have access to more farm land for cultivation after losing a portion to large-scale land investors relative to household which own small farm lands. The average farm land owned by households is 8.87 acres with a maximum and minimum of 23 acres and 4 acres respectively. (This is clearly seen from Table 1). Nega, Ulrich, Werner \& Jahn (2003) reported that landholding is a major factor constraining household farm income and household food security in Ethiopia because declining landholding due to land grabbing led to decline per capita food production and farm income, indicating that small-sized farms were not productive enough, even with improved technology.

According to Nega et al., (2003), the consequence of declining landholding size is that it reduces the fallowing practices or shortens the fallow cycle and rotation, which in turn result in declining soil quality and fertility, thereby reducing livelihoods of local communities in Ethiopia. Aside the total farm land owned by a household, the size of the portion of households' farm land lost to large-scale land investors equally influences the magnitude of effect on a household's livelihood. The regression results showed that the size of a household's farm land relinquished through large-scale land acquisition has a significant positive effect on the adverse effects that befalls on the household's livelihood as a result of large-scale land acquisition.

The empirical results indicate that the effect of large-scale land acquisition on households' livelihood increases by 16 percent for each acre of farm land lost by the household to large-scale land investors. The results of this study support the findings of Gobena (2010) who found that loss of land holding by smallholder farmers in Kebele to Indian investors had considerable negative effect on their livelihoods since land is a natural capital and the main source of livelihood to majority of farmers in Ethiopia

The regression results showed a significant negative relationship between households' participation in the land acquisition process and its' effects on their livelihoods. The empirical results revealed that households which participate in decisions leading to the acquisition of lands by large-scale land investors reduce the effects of large scale land acquisition on their livelihood by 13.1 percent. This was the prior expectation of the study. Participation of households in the decision process of investor land acquisition 
affords households the opportunity to negotiate for good terms of compensations from the investors to avert the likely effects of losing their farm lands.

This confirms the position of Mutopo et al., (2015) who found that women farmers of Nuanetsi in Mwenezi, Zimbabwe are disproportionately hit with the effects of large-scale lands acquired for crocodile farming and bio fuel plantation because they do not have representation in the provincial and district land committee to represent their rights and also negotiate for favourable eviction terms on their behalf.

"The investor's action has brought conflict between the district assembly, the traditional leaders and the small holder farmers for their non-participation during the documents negotiation. The total low output of crops, income, size of acres, and distance to farm has brought internal conflicts among state institutions and stake holders. Conflict at Adjentura between the company workers and the local farmers brought about serious injuries "hence the main motive was not achieved by all the stakeholders in the Pru district. (An interview with the Some Members of the Traditional Authority, 2020).

Access to labour by farming households has a significant negative influence on the effect of large-scale land acquisition on the livelihood of farming households. Households with access to labour averts the effects of large-scale land acquisition on its' livelihood by 19.3 percent. Households that have access to labour (family or hired) for their farming activities at newly relocated farm sites which are far from their homes maximise outputs than households without access to labour.

Companies into large-scale land activities always promise of providing training for households whose farm lands have been taken over by the company. The regression results showed a significant negative relationship between such training and the effect of losing farm lands on households' livelihoods. The empirical result indicates that training for households reduces the effect of large-scale land acquisition on households' livelihoods by 16.8 percentage. Households that received training from large-scale land investment companies are able to take up other professions for livelihood such as agro processing, dress making, and good farming practices.

"We thought after satisfying all the necessary documentation and paying for the various benefits, the ownerships of the lands would be peaceful; but, conflicts between the smallholder farmers and the 
company workers almost all the time. Our workers are at risk, also the lands nature and fertility has disappointed us contributing to low crop yields and growth "all the planned targets have not been realised (An interview with some Investors, 2020)

Off-farm activities have a significant negative influence on the effect of large-scale land acquisition on households' livelihoods. The empirical results showed that farming households engaged in other off-farm activities such as agro-processing, carpentry, mason works, food vending, and call credit vending reduce the effects of large-scale land acquisition on its livelihood by 22.6 percent.

Off-farm activities have a significant negative influence on large-scale land acquisition on households' livelihoods. The empirical results showed that farming households engaged in other off-farm activities such as agroprocessing, carpentry, mason works, food vending, and call credit vending reduce the effects of large-scale land acquisition on its livelihood by 22.6 percent.

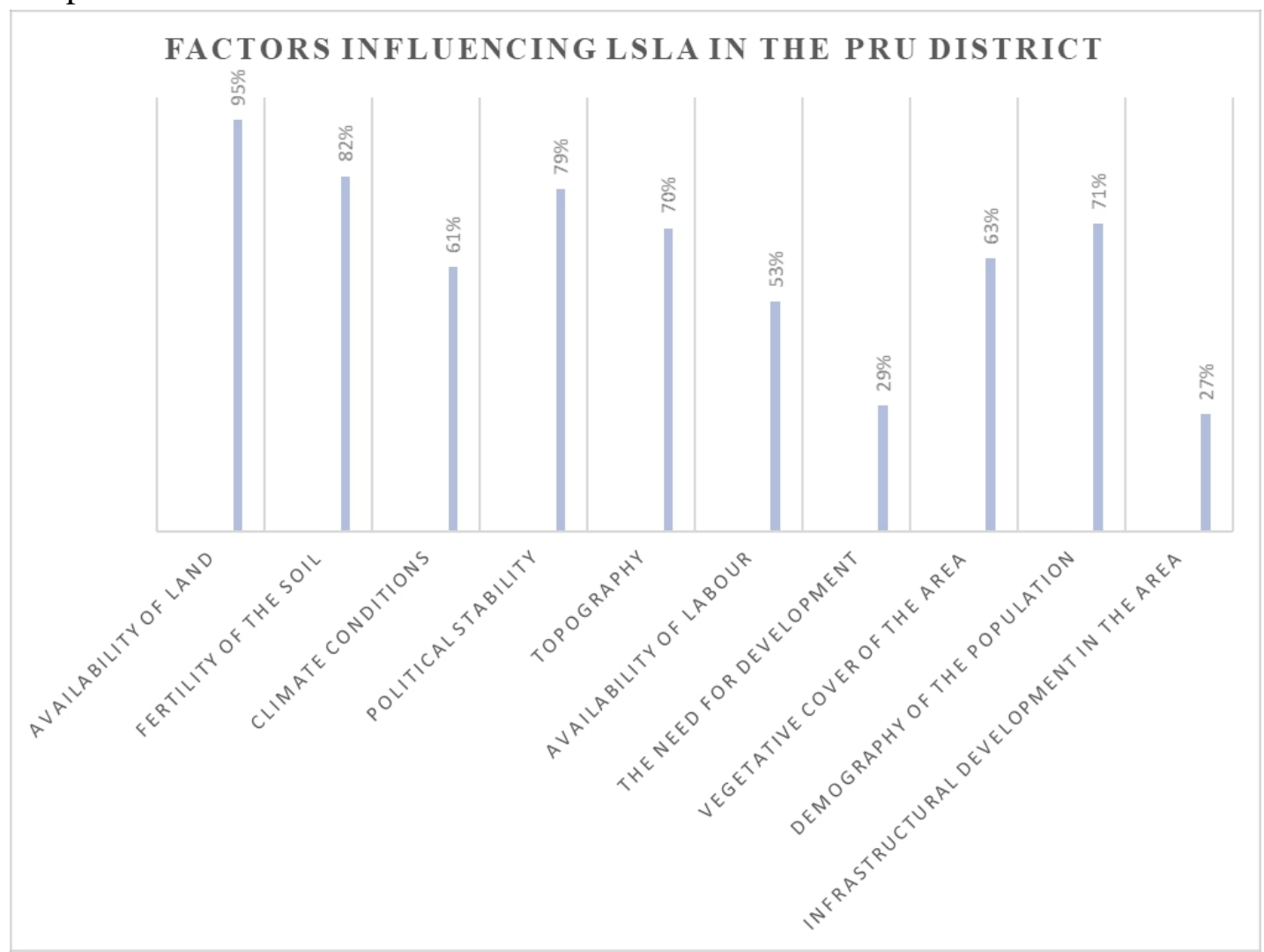

Figure 2: Factors influencing Large Scale Land Acquisition in the Pru District (Field Survey, 2020) 
Respondents from the study communities were to indicate some of the factors that has influenced the effects of large-scale land acquisition on the livelihood of smallholder farmers in the Pru district, 95 percent of the respondents attributed the influx of LSLA investors to the district, as a result of availability of land for the cultivation of their plantations as 82 percent of the respondents also indicate that the soil fertility in the district which is very good for cash crops might have influenced LSLA investors in the district. According to Aafaf, Abdelfettah, Abdesslam, Redouane, \& Abdelali (2017), water is of great importance in the study of growth and reproduction. The same way a fertile soil which has all the nutrients including water as its major component is likely to influence large-scale land acquisition by investors.

The district falls within the Interior Savannah Woodland; grasses in this vegetation grow in tussocks and can reach a height of 10 feet or more. However, due to the transitional nature of the vegetation, the area does not exhibit a typical savannah condition (GSS, 2010). The respondents affirmed that climate was a factor that contributed to the existence of LSLA in the Pru district as it was indicated by 61 percent of the respondents. However, considering topography as well as the nature of the land, 70 percent of the respondents indicated that it's one of the factors that has influence large-scale land acquisition in the Pru district, Indeed, 63 percent of the respondents also affirmed that the vegetative cover and its characteristic's moisture retention in the soil of the district was a major factor for the influx of LSLA investors in the District.

Foreign investors perceive Africa as the best destination for land investments, because it is where land can be obtained at cheaper price, without any problem on documentation, hence the motivations and decisions to secure large-scale land for plantation by investors (Ahab and Kring, 2012). In further assessing the effects of large-scale land acquisition in the Pru district, researchers inquired if political stability, the need for development, infrastructural development in the area, availability of labour and the demography of the population were also factors which have influenced the activities of large-scale land acquisition in the district.

The responses gathered proved that these factors have contributed for the influx of investors as 27 percent attributed it to the need for development, 71 percent to the demography of the population has the district boost of youths which will serve as source of labour for their planation, 79 percent indicated the political stability of the district as investors will have freedom and peace to go about their business as well as good tax exemptions and conducive atmosphere to operate in such an environment thus Pru district, availability of labour was also a factor for the concentration of the activities of LSLA investors in the Pru district, in another development, 53 percent of the 
respondents affirmed that availability of labour has influenced large-scale land acquisition activities in the Pru district.

This confirms Deininger et al., (2011) assertion that, land acquisitions are to encourage country advancement by making work, expanding profitability, and enhancing market development in the local community. Investor always consider supporting services in locating their activities as the respondents were asked if the infrastructural development of the district was a factor which influence the investors choice, 27 percent of the respondents indicated that investors have move to the Pru district because of it infrastructural development in the district. In contrary, the Pru district has been characterised with inadequate facilities.

\section{Conclusion}

The regression results revealed that household heads' education, male household heads, total farm land owned by households, households' participation in decisions leading to acquisition of large-scale of land by investors, access to labour, training of households, and households' engagement in off-farm activities have significant negative influence on the effects of large-scale land acquisition on the livelihood of smallholder farming households while the size of households' farm land lost to large scale land investors positively influences the effects of large-scale land acquisition on the livelihood of smallholder farming households. However, age of household head and access to other farming inputs have no significant influence on the effect of large-scale land acquisition on the livelihood of smallholder farming households.

The empirical results also show that household head's level of education, sex of household head, household engagement in off-farm activities, total farm land owned by a household, size of land lost by households to large-scale land investors, households' participation in decision making, and training of households for other alternative jobs significantly influence the effects of large-scale land acquisition on the livelihood of smallholder farming households

Also, since the empirical findings showed that the size of households' farm land relinquished to large-scale land investors significantly exacerbates the effects of large-scale land acquisition on the livelihood of smallholder farming households; lands which were acquired by companies whose operations are currently defunct should be returned to the initial occupants of these lands. This will be a panacea for farming households to expand production and also reduced the time spend in travelling to their farms. This is to be achieved when illegal contract between the traditional authorities, the chief and the investors are terminated and land reverted to the people when 
the companies are defunct over a certain number of years example about 5 years even before their lease contract expires.

\section{References:}

1. ActionAid (2009). Rethinking the rush to agrofuels: Lessons from Ghana, Senegal and Mozambique on the unintended consequences of agrofuels production for food security. Agricultural investment and international land deals in Africa. International Institute for Environment and Development, Food and Agriculture Organization, and International Fund for Agricultural Development, London and Rome.

2. ActionAid (2010). "Policy Briefing Paper on the Impact of Biofuel Production in Ghana".

3. Aafaf, E., Abdelfettah, M., Abdesslam, F., Redouane, M., \& Abdelali, B. (2017). Adaption of bivalve molluscs to environmental conditions in the coastal region of El Jadida (Morocco): Case of Mytilus Galloprovincialis. European Scientific Journal, 13(18), 226-241.

4. Alatinga, K. A., \& Fielmua, N. (2011). The impact of mutual health insurance scheme on access and quality of health care in Northern Ghana: The case of Kassena-Nankana east scheme. Journal of Sustainable Development, 4(5), 125-136.

5. Antwi, E., Bensah, E. C., Quansah, D. A., Arthur, R., \& Ahiekpor, J. (2010). Ghana's biofuels policy: Challenges and the way forward. International Journal of Energy and Environment, 1(5), 805-814.

6. Behrman, J., Meinzen-Dick, R., \& Quisumbing, A. (2012). The gender implications of large- scale land deals. Journal of Peasant Studies, 39(1), 49-79.

7. Biofuels International (2007). Feedstock Trends: Jatropha”. Non-food feedstocks are playing a vital role in the biodiesel market, both for economic and environmental reasons. Retrieved from http://www.emergingmarkets.com/biodiesel/pdf

8. Borras, S., \& Franco, J. (2010). Towards a broader view of the politics of global land grab: Rethinking land issues, reframing resistance. ICAS Working Paper series No. 001. Initiatives in Critical Agrarian Studies, Netherland, Bischofliches Land Deals Politics Institute and Transnational Institute.

9. Bosch, C., \& Zeller, M. (2013). The impacts of wage employment of jatropha plantation on income and food security of rural households in Madagascar: A panel data analysis. Quarterly Journal of International Agriculture, 52(2), 119-140. 
10. Chambers, R., \& Conway, G. (1992). Sustainable rural livelihoods: Practical concept for the 21st century. IDS Discussion Paper 296, Brighton

11. Cotula, L., Vermeulen, S., Leonard, R., \& Keeney, J. (2009). Land grab or development opportunity? Agricultural investment and international land deals in africa. London/Rome: IIED/FAO/IFAD. Retrieved from http://www.fao.org/3/a-ak241e.pdf.

12. Daley, E. (2011). Gendered impacts of commercial pressures on land. Commercial Pressures on Land; International Land Coalition, Rome, Italy

13. Danso, W. (2015). Land grabbing for Jatropha Bio-fuel in Ghana: Assessing the impact on households' livelihood in Northern Ghana. Noragric, Department of International Environment and Development Studies. Norwegian University of Life Sciences, Norway

14. Deininger, K., \& Byerlee, D. (2011). Rising global interest in farmland: Can it yield sustainable and equitable benefits? London: The World Bank.

15. DFID (1991). Sustainable livelihoods guidance sheets. London: DFID.

16. DfID. (2000). Sustainable livelihoods guidance sheets. Retrieved from wwwlivelihoods.org

17. Ellis, F. (2000). Rural livelihoods and diversity in developing countries. Oxford university press

18. Energy Center (2008). A review of renewable energy sources, sustainability issues and climate change mitigation. Retrieved from https://www.cogentoa.com/article

19. Food and Agriculture Organization (2013). The gender and equity implications of land-related investments on land access, labour and income-generating opportunities in Northern Ghana: The case study of integrated Tamale Fruit company. Retrieved from atwww.fao.org/docrep/018/aq535e/aq535e.pdf.

20. Food and Agriculture Organization (FAO), (2012). The state of food and agriculture. Investing in agriculture for a better future. International Institute of Environmental Development (IIED) UK. Retrieved from http://www.fao.org/docrep

21. Friis, C., \& Reenberg, A. (2010). Land grab in Africa emerging land system drivers. Retrieved from http://scholar.google.com

22. Gexsi, L. L. P. (2008). Global market study on Jatropha. World Wide Fun for Nature (WWF), London/Berlin.

23. Gobena, M. (2010). Effects of large-scale land acquisition in rural Ethiopia: The case of Bako-Tibe Woreda. Unpublished Doctoral dissertation, Swedish University of Agricultural Sciences, Uppsala, Sweden. 
24. Hall, J. (2008). 'Cross-sectional survey design' in Lavrakas P.J. (ed.) Encyclopedia of Survey Research Methods, pp. 173-174. Thousand Oaks, CA: SAGE Publications, Inc.

25. Hamenoo, S. V. Q. (2014). The effects of large-scale land acquisition for jatropha plantation on small-scale farmers in rural communities in the Asante Akim north district. Retrieved from http://doi.org/10.1017/CBO9781107415324.004

26. Herzog, M. H., Fahle, M., \& Koch, C. (2001). Spatial aspects of object formation revealed by a new illusion, shine-through. Vision Research, 41(18), 2325-2335.

27. Hughes, A. K., Knox, A., and Jones-Casey. K., (2011). Focus on Land Brief in Africa: Pressure on land from large scale biofuel production. Lesson 2. World Resources Institute in partnership with Landesa Rural Development Institute. Funded by the Bill and Melinda Gates foundation. IFAD OCCASIONAL PAPER 2.

28. Johnson, R. B., \& Onwuegbuzie, A. J. (2009). Mixed methods research: A research paradigm whose time has come. Educational Researcher, 33(7), 14-26.

29. Morse, J. M., \& Field, P. A. (1996). Nursing research: The application of qualitative approaches. London: Macmillan.

30. Kemausuor F., Akowuah J.O., \& Ofori E. (2013). Assessment of feedstock options for biofuels production in Ghana. Department of Agricultural Engineering, Kwame Nkrumah University of Science and Technology, Kumasi, Ghana. Journal of Sustainable Bioenergy Systems, 2013, 3, 119.

31. Kotey, N. A. (2002). Compulsory acquisition of land in Ghana: Does the 1992 Constitution open new Vistas? In Toulmin, C., Delville, P. L., \& Traoré. S (Eds). The dynamics of resource tenure in West Africa. London, GRET/IIED, James Currey \& Heineman.

32. German, L., Gumbo, D., \& Schoneveld, G, (2012). Large-scale investments in Chitemene Farmland: Exploring the marginal lands narrative in Zambia's Northern Province. European Union and University of Georgia, United States of America

33. Levidow, L., \& Paul, H. (2010). Global agrofuel crops as contested sustainability, Part I: Sustaining what development? Capitalism Nature Socialism, 21(2), 64-86.

34. Matondi, P. B., Havnevik, K., \& Beyen, A. (n.d). Introduction: biofuels, food security and land grabbing in Africa

35. Mutopo, P., Chiweshe, M. K., \& Mubaya, C. P. (2015). Large-scale land acquisitions, livelihoods, and gender configurations in Zimbabwe. Handbook of Research on In-Country Determinants and Implications of Foreign Land Acquisitions, 130-144. 
36. Nega, E., Ulrich, R., Werner, S., \& Jahn, M. (2003). Hot water treatment of vegetable seed: An alternative seed treatment method to control seed-borne pathogens in organic farming. Journal of Plant Diseases and Protection, 220-234.

37. Quisumbing, A. R. (2003). Household decisions, gender, and development: A synthesis of recent research. Washington, D.C.: International Food Policy Research Institute.

38. Ahab, Z. H. M., \& Kring, S. (2012). The impact of larger scale agricultural investments on communities in South East Asia: A first assessment. Retrieved from http://journals.openedition.org/poldev

39. Schoneveld, G. C., German, L. A., \& Nutakor, E. (2011). Land-based investments for rural development? A grounded analysis of the local impacts of biofuel feedstock plantations in Ghana. Ecology and Society, 16 (4), 10-18.

40. Schoneveld, G. C., German, L. A., \& Nutakor, E. (2010b). Towards sustainable biofuels development: Assessing the local impacts of large-scale foreign land acquisitions in Ghana. Washington, DC: World Bank, 1-7.

41. Sindayigaya, W. (2011). Foreign investments in Agriculture: Land grabbing. Retrieved from http://www.entwicklungshilfe3.de/fileadmin

42. Thurmond E., (2007). Feedstock trends: Jatropha. Retrieved from http://www.emerging-markets.com 